\title{
Flood Risk Management in the European Union
}

\author{
Clemens NEUHOLD ${ }^{1}$
}

\author{
${ }^{I}$ Federal Ministry of Agriculture, Forestry, Environment and Water Management, Flood Risk Management Division, Vienna, Austria, \\ clemens.neuhold@bmlfuw.gv.at
}

\begin{abstract}
The purpose of the Directive 2007/60/EC on the assessment and management of flood risks (FD) is to establish a framework for the assessment and management of flood risks, aiming at the reduction of the adverse consequences for human health, the environment, cultural heritage and economic activity associated with floods in the Community. The end of the 1st cycle (2009-2015) and the beginning of the 2nd cycle of implementation (2016-2021) of the "Floods" Directive (2007/60/EC) gives an opportunity to improve the delivery of the requirements of the Directive and share 1st cycle experiences, including successes and lessons learned.

A questionnaire devised to spark a reflection of the past six years and contemplation for the forthcoming six years was sent to EU Member States in January 2016. By mid-2016, all 28 Member States submitted a completed questionnaire - a fantastic achievement. A copy of the questionnaire is included in Appendix A of an extensive report (https://circabc. europa.eu/w/browse/4b8f494d-5da8-4e0d-9695-b2378a53db09). Results of the questionnaire also served to organise and facilitate a workshop in April 2016 in Vienna, Austria where relevant topics of lessons learnt during the first cycle of implementation as well as implications for the second cycle of implementation were discussed. This paper gives and overview of "big issues" and relevant conclusions.
\end{abstract}

Key-words: EU-Floods Directive, Flood Risk Management, first cycle of implementation

\section{La gestion du risque d'inondation à l'Union Européen}

\begin{abstract}
RÉSUMÉ. - La directive 2007/60/CE sur l'évaluation et la gestion des risques d'inondation (FD) consiste à établir un cadre pour l'évaluation et la gestion des risques d'inondation, qui vise à réduire les conséquences négatives pour la santé humaine, l'environnement, le patrimoine culturel et l'activité économique associée aux inondations dans la Communauté. La fin du 1er cycle (2009-2015) et le début du 2ème cycle de mise en œuvre (2016-2021) de la directive «Inondations» (2007/60 / CE) donnent l'occasion de faire un retour d'expérience sur le 1er cycle, y compris les réussites et les leçons apprises. Un questionnaire relatif au bilan sur les six dernières années et à une prospective sur les six prochaines années a été envoyé aux États membres de l'UE en janvier 2016 : cf. annexe A d'un rapport détaillé (https:/circabc.europa. eu/w/browse/4b8f494d-5da8-4e0d-9695-b2378a53db09). À la mi-2016, les 28 États membres avaient rempli le questionnaire - une réussite fantastique. Les résultats du questionnaire ont également servi à organiser et à faciliter un atelier en avril 2016 à Vienne, en Autriche, où les leçons tirées au cours du premier cycle de mise en œuvre ont été discutées ainsi que des perspectives pour le deuxième cycle de mise en œuvre. Cet article donne un aperçu des grands enjeux et des conclusions pertinentes.
\end{abstract}

Mots-clés : directive inondation, gestion du risque d'inondation, premier cycle d'implémentation

\section{IMPLEMENTING THE EU WATER FRAMEWORK DIRECTIVE (2000/60/EC) AND THE EU FLOODS DIRECTIVE (2007/60/EC)}

The implementation of the Water Framework Directive raises a number of shared technical challenges for the Member States, the Commission, the Candidate and EEA Countries as well as stakeholders and NGOs. In addition, many of the European river basins are international, crossing administrative and territorial borders and therefore a common understanding and approach is crucial to the successful and effective implementation of the Directive.

In order to address the challenges in a co-operative and coordinated way, the Member States, Norway and the Commission agreed on a Common Implementation Strategy (CIS) for the Water Framework Directive only five months after the entry into force of the Directive.

The results of this work, for instance guidance documents on technical aspects elaborated in the context of the
CIS, key events and additional resource documents related to different aspects of the implementation are available on CIRCABC. The documents which are prepared in the context of the Common Implementation Strategy and many other useful documents are available on a specific information exchange platform which was set up for this process, the so-called WFD CIRCA Interest Group "Implementing the Water Framework Directive and the Floods Directive".

More details on the overall concept, the numerous activities and the mandates of the Working Groups under the Common Implementation Strategy are given in the Work Programmes informally agreed by the EU Water Directors.

The Common Implementation Strategy also supports the Commission in delivering its obligations for further policy development (Daughter Directives on Groundwater and on Priority Substances).

In addition, Directive 2007/60/EC on the assessment and management of flood risks is closely coordinated with the 


\section{CIS Organisation 2016-2018}

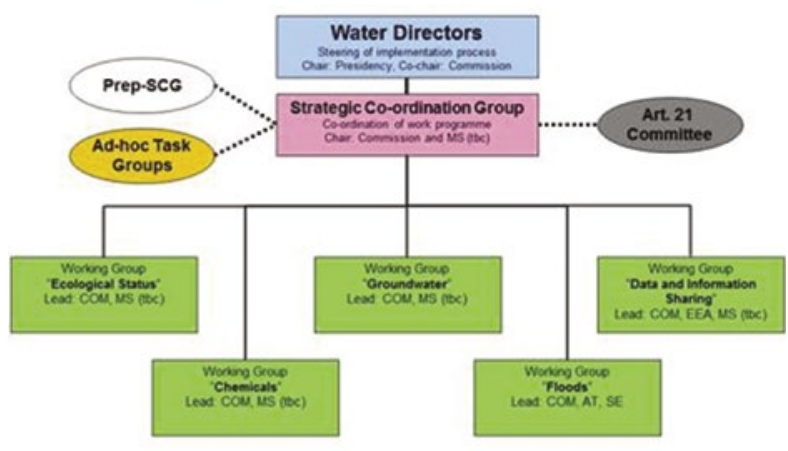

Figure 1 : Organigram of the Common Implementation Strategy for the work program period of 2016-2018

Water Framework Directive. The Common Implementation Strategy therefore also supports the implementation of the Floods Directive through the Working Group on Floods.

\section{CIS WORKING GROUP "FLOODS" (WG F)}

The purpose of WG $\mathrm{F}$ is to provide a forum to support the implementation of the Floods Directive by providing for: - information exchange between Member States, the Commission and stakeholders on good practices, policy, research and project developments and new approaches to enhance flood risk management in Europe, and,

- feedback on the implementation of the Directive and its reporting with a view to reaching a common understanding on the requirements for the implementation of the Floods Directive and efficient and effective reporting, and,

- linking with related activities of the Common Implementation Strategy (CIS) at EU level, and with other Commission or international activities for support of the implementation.

\section{THE DIRECTIVE 2007/60/EC}

Floods have the potential to cause fatalities, displacement of people and damage to the environment, to severely compromise economic development and to undermine the economic activities of the Community.

The EU Directive on the assessment and management of flood risks [2007/60/EC], often referred to as the 'Floods' Directive, was adopted on 23 October 2007. Its aim is to reduce and manage the risks that floods pose to human health, the environment, cultural heritage and economic activity. The approach is based on a six year cycle of planning, subject to the application of transitional arrangements. The development of a Floods Directive was considered after the huge and devastating floods that struck Central Europe in 2002. It came into force with a principal objective to reduce the risk of floods and to take future changes in the risk of flooding as a result of climate change into account.

The FD is to be implemented in Member States in three stages. During the first stage, the EU Member States should have carried out Preliminary Flood Risk Assessments (PFRAs) for river basins and for coastal zones by 22
December 2011, in order to identify areas of existing or foreseeable future potentially significant flood risk (referred to as 'Areas of Potentially Significant Flood Risk (APSFRs)). An important concept in the FD is flood risk. This is a combination of the probability of the flood occurring and its consequences.

During the second stage, Member States should prepare flood hazard maps and flood risk maps for the APSFRs identified by 22 December 2013. These should identify areas prone to flooding during events with a high (optional), medium and low probability of occurrence, including those where occurrences of floods would be considered an extreme event. The maps will also have to include details of expected flood extent and water depths (flood hazard maps) and economic activities that could be affected, the number of inhabitants at risk and the potential environmental damage (flood risk maps).

The third stage will require Member States to produce catchment-based Flood Risk Management Plans (FRMPs) by 22 December 2015, thereby harmonizing with the WFD River Basin Management Plan (RBMP) cycle. The FRMPs will be focused on prevention, protection and preparedness, setting objectives for managing the flood risk within the APSFRs and setting out a prioritised set of measures for achieving those objectives. Member States should coordinate their flood risk management practice in shared river basins, including with third counties, and shall not undertake measures that would increase the flood risk in neighbouring countries.

Member States should also take into consideration long term developments, including climate change, as well as sustainable land use practices in the flood risk management cycle addressed in the FD. All assessments, maps and plans prepared shall be made available to the public, and Member States are required to encourage the active involvement of interested parties in the preparation of the FRMPs.

To summarise the FD is designed to:

- establish a framework for the assessment and management of flood risks, aiming at the reduction of the adverse consequences for human health, the environment, cultural heritage and economic activity associated with floods in the Community;

— establish a process for producing flood hazard maps and flood risk maps in order to address the flood risk;

— in the flood risk management plans address all aspects of flood risk management focusing on prevention, protection, preparedness, including flood forecasts and early warning systems and taking into account the characteristics of the particular river basin or sub-basin.

The FD planning cycle is aligned with that of the WFD and there is a requirement for coordination of the two Directives. It is important to note that, as of October 2013, the first Flood Risk Management Plans have yet to be produced and hence Member States are still undergoing a learning process in how the synergies between the FD and WFD can be taken advantage of at a practical level (EC, 2014).

\section{WORKSHOP ON LESSONS LEARNT DURING THE $1^{\text {st }}$ CYCLE OF IMPLEMENTING THE EU-FLOODS DIRECTIVE}

The workshop was held from 12th-14th April, 2016 in Vienna, Austria. Based on a comprehensive questionnaire plenary and break-out sessions had been organised. 
Starting with a key note session the aspects on Preliminary Flood Risk Assessment (PFRA), delineation of Areas of Potential Flood Risk (APSFR), Flood Hazard and Risk Maps (FHRM), Flood Risk Management Plans (FRMP), links to other Directives and Reporting according to the FD were presented and discussed.

Before the FD was adopted there had been a variety of methods that were used for flood risk management. These fall into three categories:

- Various legislation, regulations and policies at municipal, regional and national levels;

- Various types of strategies and plans for different types of floods (e.g. fluvial, coastal, surface water);

- Various methods for prioritising flood defence and risk management measures (e.g. cost-benefit analysis, areas where floods had occurred previously) as well as measures in the frame of disaster risk reduction.

\section{IV.1. Preliminary Flood Risk Assessment (PFRA) and delineation of Areas of Potential Significant Flood Risk (APSFR)}

The PFRA highlighted that in terms of hazard information e.g. past floods, a good stock is in place. For vulnerability data there is good information on direct damages available but also a need to improve data with respect of indirect and intangible effects.

In the frame of the PFRA the definition of significance is of highest priority which had been approached by different methods, such as:

- multi-criterial analysis

- definition of thresholds

- expert judgement

- political decision

Further the types of floods to be considered and how to associate significance to them poses a major challenge for MSs. The example of fluvial and pluvial floods had been mentioned several times in terms of good available data on gauging stations related to recurrence interval for fluvial floods in contrast do defining recurrence intervals for precipitation, regionalizing them, etc. in the frame of assessing pluvial flood risk.

\section{IV.2. Flood Hazard and Risk Maps (FHRM)}

The main challenges in the frame of production of flood hazard and risk maps besides a very tight time schedule were:

- the lack of and quality/resolution of data (e.g. DTM, river surveys, sea levels, ephemeral flows);

- Lack of a quantitative methodology for certain types of floods (e.g. flash floods, pluvial floods, groundwater floods, sewer flooding, ice jams).

Built on these information gaps it also makes it very challenging how to communicate the - uncertain - results in an appropriate and understandable manner for a range of different stakeholders and users (e.g. public, emergency planners, EU).

\subsection{Flood Risk Management Plan (FRMP)}

With regards to the positive impacts of implementing the FD improvements in and strengthening of coordination and collaboration between different sectors (e.g. flood protection, emergency planning spatial planning), decision makers and other stakeholders (e.g. public, local authorities) at different spatial scales were noted as being areas where the FD had been beneficial. However, as most of our decisions are based on experiences made in the past an anticipatory approach would foster a more comprehensive risk management in terms of considering human interventions, socio-economic development and climate change.

In terms of the influence of the FD on flood risk management there had been:

- A change in approach from flood protection towards a systematic, coordinated and holistic implementation of flood risk management plans and measures;

- An increase in cooperation and collaboration between various stakeholders responsible for emergency management, land use planning and flood risk management;

- Other influences e.g. coordinated approach; moved focus from flood hazard to flood risk; increased awareness of flood risk ; links to spatial planning ; improvement of flood warning data and information systems ; and, introduction of new commissions.

The implementation of the EU Floods Directive clearly strengthened the coordination and harmonisation across sectors, administrational levels and stakeholders addressing the needs for action for water management, flood protection, spatial planning, emergency planning, etc. The obligation to review the process and to revise relevant information in the frame of a cyclic work flow supports a sustainable approach by discussing achievements and deficits transparently significantly supporting awareness raising as well as public information and consultation.

\section{REFERENCE}

European Commission (2014): Links between the Floods Directive (2007/60/EC) and the Water Framework Directive (2000/60/EC). Resource Document. Technical Report 2014078.

\section{ACKNOWLEDGMENTS}

Thanks to my dear colleagues, namely Barbro Näslund-Landenmark, Mark Adamson and Ioannis Kavvadas, for reviewing the paper. 